\title{
Lily Royor, Maengket, and Mah'zani Dance Song Lyrics in Minahasa
}

\author{
Victorien Katuuk $^{1 *}$, Rina P. Pamantung ${ }^{2}$
}

\author{
1,2 Sam Ratulangi University \\ *Corresponding author: Email: victorienkatuuk@gmail.com
}

\begin{abstract}
Lily Royor, Maengket, and Mah'zani dances are the original Minahasa culture. Therefore, the purpose of this paper is to review the lyrics of the dances of Lily Royor, Maengket, and Mah'zani. Two problems were discussed: 1) What are the linguistic form of the Lily Royor, Maengket, and Mahzani dance lyrics, 2) what is the meaning of the Lily Royor, Maengket, and Mah'zani dance lyrics. This research was conducted to maintain language and culture. The research method used is a qualitative descriptive method [1] with an ethnographic approach. Linguistic Anthropology that connects language and culture by Foley [2], Sibarani [3], and Van Dijk [4],), and Eriyanto [5]. The data collection technique followed Sudaryanto [6] to record and tap language data. The Basic Theory of Linguistics, namely, Morphology, Syntax and Semantics, is used to analyze the version of the lyrics of the Lili Royor song that accompanies the Lili Royor dance and the meaning contained in the lyrics of the Lili Rroyor song. Morphological theory, explains the smallest meaningful language units from the theories of Nida [7], Wouw [8], and Verhaar [10]. Meanwhile, the Semantic theory with semantic analysis from Lyon (1976) and cultural meaning uses the theory from Spradley [11], and Christomy [12] theory to answer the cultural meaning. The result of the research is that the theme of the song lyrics is similar to the lyrics of the song Maengket or Mah'zani, namely the theme of prayer, youth romance, love, joy, and harvest according to the standard of the reality of life experienced by humans or people who live in the Minahasa region. The theme of the Lily Royor dance which is different from other dances in Minahasa is the theme of "loving the youngest sister" in the sense that "the youngest brother is also prioritized as the eldest child in a single-family". That theme never existed in Maengket and Mah'zani. Furthermore, the lingual form is different from the lingual form used in other dances in Minahasa. For example, the appearance of [i-] attached to the root word of the verb, namely ilampang 'walks', ipayos 'swaying', Ileon 'play'. I catfish the lingual form [i-] is clitic because the attachment of [i-] to the root word of the verb produces the meaning "lah". A vowel /i/ occurs alongside the root verb and is not a bound morpheme. On the other hand, the use of / $\mathrm{i} /$ in the word in Maengket dance means possessiveness, namely ownership or belonging to someone, for example, Iya'i 'owner of this land Opo' and iti'i 'respectively'. While the use of $\mathrm{i}$ - in the Mah'zani dance is a disciplined value in various aspects of people's lives as a guide and orientation for the life of the Tombulu people today. Lily Royor's lingual form consists of morphemes and words that have undergone affix processes such as prefixes, confixes, infixes and suffixes as well as reduplications and imperative forms in the accompanying song for the Lili Royor dance.
\end{abstract}

Keywords: "Dance, Lily Royor, Maengket, Mah'zani, lyrics, clitic"

\section{INTRODUCTION}

Lily Royor, Maengket, and Mah'zani dances are the original Minahasa culture. Therefore, the purpose of this paper is to review the lyrics of the dances of Lily Royor, Maengket, and Mah'zani. In this regard, Minahasa as the largest region in North Sulawesi Province has a well-known cultural tradition of dances, although not all dance names are known on a local, national, or international scale. The name of the dance is the original dance from Minahasa, namely 1) Mahzani dance, 2) Maengket dance, 3) Marambak dance, 4) Makamberu dance, 5) Makaaruyen dance, and 6) Lily Roror dance. The dance is often appointed as research by language and cultural researchers or sympathizers of Minahasa culture. However, a more in-depth study of dance in Minahasa still 
needs to be done to complete the documentation in the context of language and cultural defence efforts. In addition, so that the Minahasa cultural heritage in the form of dance can be known by the younger generation.

Each dance has its uniqueness and uniqueness. The Maengket dance is best known to the public, even though the first to appear is the Mahzani dance. Meanwhile, the Lily Royor dance is one of the dances that only appears in the area where the Tonsea language is spoken. Maengket dances appear throughout the Minahasa region. The dance that appears in the Tomohon Municipality area is the Mahzani dance.

Lily Royor, Maengket, and Mahzani dances are considered to represent dances in Minahasa as a cultural heritage that needs to be observed. Therefore, the three dancers were appointed as topics in this discussion so that a more in-depth study would be obtained to obtain accurate results. The discussion focused on language and culture.

There are two issues discussed, namely: 1) What are the lingual form of the Lily Royor, Maengket, and Mahzani dance lyrics, 2) what is the meaning of the Lily Royor, Maengket, and Mah'zani dance lyrics.

\section{METHODOLOGY}

This research was conducted to maintain language and culture. The research method used is the descriptive qualitative method [1] with ethnographic and synchronic linguistic approaches. Linguistic Anthropology that connects language and culture by Foley [2], Sibarani [3], and Van Dijk [4], and Eriyanto [5]. The data collection technique followed Sudaryanto [6] to record and tap language data. Researchers conducted interviews by asking descriptive questions as referenced from [11]. Description questions consist of 5 core questions such as a) grand tour questions, b) mini-tour questions, c) sample questions, d) experience questions, e) native language questions. The data of Lily Royor, Maengket and Mah'zani dance song lyrics were identified and qualified. After that, it is analyzed according to the theory that has been chosen.

The basic theory of linguistics, namely, morphology, syntax and semantics are used to analyze the lyrics of the Lili Royor song, the Maengket dance, and the Mahzani dance. Morphological theory, explains the smallest meaningful language units from the theories of Nida [7], Wouw [9], and Verhaar [10]. The syntactic theory of Givon (1981). Meanwhile, Semantic theory with special semantic analysis of meaning from Lyon (1976), Leech [13] and cultural meaning uses theories from Van Dijk [4] Spradley
[11], and Christomy [12] theory to answer cultural meanings.

One branch of linguistics that identifies the basic units of language as grammatical units is called morphology, while the smallest grammatical unit is morpheme which includes basic morphemes and affixed morphemes [10]. Nida [7] explains that six principles can be used to identify the morphemes of a language. Bickford et al (1991) explained the techniques for identifying morphemes, namely: 1) Finding repetitive parts with fixed meanings and 2) Finding contrasts in a framework.

The syntactic analysis uses the syntactic theory of Givon (2003), while the theory of meaning from Leech [13] uses the theory of semantics and cultural meaning from Spradley [11] and Rahyono (2009), cultural semiotics by Christomy [12]. Van Dijk [4] uses and takes the linguistic analysis of vocabulary, sentences, propositions and paragraphs to explain and interpret a text. According to him, social cognition is a dimension to explain how a text is produced by individuals/groups of text makers. Leech [13] states that meaning consists of denotative and connotative meanings. The denotative meaning is the actual meaning of the word. The denotative meaning is the same as the conceptual meaning. The connotative meaning is the meaning outside of the real meaning. The figurative or metaphorical meaning of the word. Christomy [12] explains that meaning is a cultural unit and each pattern of meaning is the result of conventions in human culture.

\section{ANALYSIS}

The three dances that are the focus of the study are the Lily Royor dance, the Maengket dance, and the Mahzani dance. The dance is located in the Minahasa region, as part of North Sulawesi Province. The results of the research and discussion of the Lily Royor dance lyrics, Maengket dance, and Mahzani dance are as follows.

\subsection{Lingual form and meaning of Lily Royor, Maengket and Mahzani dances.}

\subsubsection{Lingual form of Lily Royor, MaengketdanMahzani dances.}

Mahzani dance is a type of dance that is still practised in society, both when working together (Mapalus group), or when holding meetings or certain events. The Tombulu community, especially rural farmers in Woloan village, practice Mahzani singing along with working hours in the Mapalus group. This song turns out to be able to relieve someone's tiredness at work, then increase one's work spirit. The structure of the song has uniformity in three major parts: the introduction, the content of the song or the idea to be conveyed, 
then the closing part. The lingual form consists of words, phrases, and sentences. Words consist of single words and prefixes.

The Maengket dance, which is a superstructure, has an introduction, content, and closing, there are three rounds in the Maengket traditional dance performance. In its development, traditional dances are performed for various purposes such as:

Welcoming Ceremony, Harvest, and Art performances, and Thanksgiving events.

The lingual form of the Maengket dance is also similar to the Mahzani dance. The form of the word in the Maengket dance means possessiveness, namely ownership or belonging to someone, for example, Iya'i 'owner of this land Opo' and iti'i 'respectively'. The lyrics of the Maengket Dance song have a narrative structure coloured by singing from the direct messenger to other participants which greatly determines the wholeness and mood which includes speech and perspective. The formal structure has textual characteristics as a linguistic unit with a poetic style and includes the relationship between sentences, words, and sounds in macro, superstructure, and micro.

The lily Royor dance has a four-act structure. The dance was performed to entertain at the Thanksgiving event. The lingual form of the Lily Royor dance lyrics are words, phrases, and clauses. Klitika appears in the words ilampang, ilingkoya, idani, ipayos, and ilele. I is not a prefix but a clitic form. For example, the appearance of [i-] attached to the root word of the verb, namely ilampang 'walk', ipayos 'swaying', Ileon'play'. I catfish. The lingual form [i-] is clitic because the attachment of [i-] to the root word of the verb produces the meaning "lah". Lily Royor's lingual form consists of morphemes and words that have undergone affix processes such as prefixes, confixes, infixes and suffixes as well as reduplications and imperative forms in the accompanying song for the Lili Royor dance.

The theme of the song's lyrics is similar to the lyrics of the song Maengket or Mah'zani, namely the theme of prayer, youth love, love, joy, and reaping according to the standard of the reality of life experienced by humans or people who live in the Minahasa region. The theme of the Lily Royor dance which is different from other dances in Minahasa is the theme of "loving the youngest sister" in the sense that "the youngest brother is also prioritized as the eldest child in a singlefamily". That theme never existed in Maengket and Mah'zani.

\subsubsection{The meaning of Lily Royor, Maengket and Mahzani dances.}

The meaning of Lily Royor, Maengket and Mahzani dances are denotative, connotative meaning, and cultural meaning. The lingual form consists of words, phrases, and sentences. Words consist of single words and prefixes. The denotative meaning appears in the sentences in the Maengket and Mahzani dances. The connotative meaning is found in the Lily Royor dance. The figurative meaning is in the sentence

1. wenduuman un sumosod, menangkenturrambu-rambunan

'It's tiring to climb a dense high mountainwith trees'

Taansakita mine kasosodorumumber pa rege-regesanmulus

But when we have reached the peak, then we have fun up there with fresh air, blown by a cool breeze'

2. Maesalalanlampangan

'Unite the paths traversed'

Ilele um pancasila

'Hold on to Pancasila'

Maesakita. Lili royor e

'United us, my dear'

3. Minekadiputungkenturtamporok

'Around Mount Tamporok (Klabat)'

KenturrakekwiaMinaesa

'High mountain in Minahasa'

Kuramoungkerakekkenturtamporok

'As high as Mount Tamporok'

Tentumongkerakekgenangta

'That's how high my goals are'

3.2 The similarities and differences between the Lily Royor dance, the Maengket dance, and the Mahzani dance are as follows.

3.2.1 The similarities between the Lily Royor dance, the Maengket dance, and the Mahzani dance are as follows.

All three are regional dances as cultural heritage originating from the Minahasa dance area. The Mahzani dance appeared first, followed by the Maengket dance, and the Lily Royor dance. The three dances use local language song lyrics in Minahasa.

\subsubsection{The differences between Lily Royor} dance, Maengket dance, and Mahzani dance are as follows.

The theme of the song's lyrics is similar to the lyrics of the song Maengket or Mah'zani, namely the theme of prayer, youth love, love, joy, and reaping according to the standard of the reality of life experienced by humans or people who live in the Minahasa region. The theme of the Lily Royor 
dance which is different from other dances in Minahasa is the theme of "loving the youngest sister" in the sense that "the youngest brother is also prioritized as the eldest child in a singlefamily". That theme never existed in Maengket and Mah'zani.

The structure of the Maengket and Mahzani dances is the same, namely three stages. This is because there is a close relationship between the Mahzani and Maengket dances. According to Riedel's research, the Mahzani dance is the mother of the Maengket dance. The characteristics of the song's lyrics are similar, except that the Maengket dance is found in all areas of local language use in Minahasa. The Lily Royor dance has a four-act structure. The dance is only found in the area where the Tonsea language is spoken. The Lily Royor dance has several versions according to the village where the dance is from, namely the Kaasar version of the Lily Royor dance, the Manembo-nembo version, and the Airmadidi version. The lingual form of Lily Royor dance has klitik, on the other hand klitik is not found in the Maengket dance and the Mahzani dance. The meaning of the lyrics of the Maengket and Mahzani dance songs contain denotative meanings. Meanwhile, connotative eating is found in the lyrics of the Lily Royor dance song. The word GunungKlabat refers to high ideals as high as Mount Klabat. The word ideal is used to describe the high Klabat mountain.

\section{CONCLUSION}

The forms and meanings of the Lily Royor, Maengket, and Mahzani dances are the lingual forms consisting of words, phrases, and sentences. Words consist of single words and prefixes. Lily Royor's dance song lyrics have an i-'lahcliche. The meanings of Lily Royor, Maengket and Mahzani dances are denotative meaning, connotative meaning, and cultural meaning.

The difference between Lily Royor dance, Maengket dance, and Mahzani dance is the theme and structure of the dance. Lily Royor dance theme contains the main theme of loving the youngest sister. Maengket and Mahzani dances are dances at harvest time. The Lily Royor dance was performed as entertainment at the Thanksgiving event.

\section{ACKNOWLEDGMENT}

First of all, Thank you to Almighty God. We are extremely great. We also would like to say thank you very much to all those people who have given us motivation, encouragement, and advice. Thank you also to Atalantis Star for accepting the articles. Finally, we hope the articles can be useful for the readers.

\section{REFERENCES}

[1] Denzin, Norman K \& Lincoln, Yvonna S. (eds.). 2009. Handbook of Qualitative

[2] Folley, W.A. 1997. Anthropological Linguistics, An Introduction. Malden: Blackwell Publishers, Inc

[3] Sibarani, R. 2012. Kearifan Lokal. Hakikat, Peran, Dan MetodeTradisi Lisan.

[4] Van Dijk, T.A. 1985. Handbook of Discourse Analysis Volume 1. Disciplines of

[5] Eriyanto. 2009. AnalisisWacana. Pengantar

[6] Sudaryanto, 2015. Metode Dan Aneka TeknikAnalisis Bahasa.Pengantar

[7] Nida, E.A. 1949. Morphology. The Descriptive Analysis of Words. Ann Arbor

[8] Wouw, J. van de. 1973. Bahan untuk Tata Bahasa Tombulu. Mimeograf yang di perbanyak dan diedarkan oleh Pusat Dokumentasi Bahasa-bahasa Daerah, STFT Driyarkara. Jakarta Pusat.

[9] Wouw, J. van de. 1971. A Nuwu' Ne Tombulu' Rinewok Wo Ni ImekPina'TuliTulian Ni Pastor Ne Toumu'ung. Sinawang Ni MesterTu'a. Tomohon: mimeograph.

[10] Verhaar, J.W.M. 2001. Asas- Asas Linguistik Umum. Yogyakarta: GadjahMada University Press.

[11] Spradley, J. 1979. The Etnographic Interview. Belmon California: Wadsworth

[12] Christomy, T \&Yuwono U, 2010. SemiotikaBudaya. Depok: PusatPenelitian

[13] Leech, G. 1981. Semantics. The Study of Meaning. Suffolk, Great Britain: Richard 